\title{
Large Gliadin Peptides Detected in the Pancreas of NOD and Healthy Mice following Oral Administration
}

\author{
Susanne W. Bruun, ${ }^{1}$ Knud Josefsen, ${ }^{1}$ Julia T. Tanassi, ${ }^{2}$ Aleš Marek, ${ }^{3,4}$ \\ Martin H. F. Pedersen, ${ }^{3}$ Ulrik Sidenius, ${ }^{5}$ Martin Haupt-Jorgensen, ${ }^{1}$ Julie C. Antvorskov, ${ }^{1}$ \\ Jesper Larsen, ${ }^{1}$ Niels H. Heegaard, ${ }^{2}$ and Karsten Buschard ${ }^{1}$
}

\author{
${ }^{1}$ The Bartholin Institute, Rigshospitalet, Copenhagen N, Denmark \\ ${ }^{2}$ Clinical Biochemistry, Immunology \& Genetics, Statens Serum Institut, Copenhagen S, Denmark \\ ${ }^{3}$ The Hevesy Laboratory, DTU Nutech, Technical University of Denmark, Roskilde, Denmark \\ ${ }^{4}$ Institute of Organic Chemistry and Biochemistry, Academy of Sciences of the Czech Republic, Prague 6, Czech Republic \\ ${ }^{5}$ Enzyme Purification and Characterization, Novozymes A/S, Bagsvord, Denmark
}

Correspondence should be addressed to Knud Josefsen; knud@eln.dk

Received 6 May 2016; Accepted 10 August 2016

Academic Editor: Marco Songini

Copyright (C) 2016 Susanne W. Bruun et al. This is an open access article distributed under the Creative Commons Attribution License, which permits unrestricted use, distribution, and reproduction in any medium, provided the original work is properly cited.

\begin{abstract}
Gluten promotes type 1 diabetes in nonobese diabetic (NOD) mice and likely also in humans. In NOD mice and in non-diabetesprone mice, it induces inflammation in the pancreatic lymph nodes, suggesting that gluten can initiate inflammation locally. Further, gliadin fragments stimulate insulin secretion from beta cells directly. We hypothesized that gluten fragments may cross the intestinal barrier to be distributed to organs other than the gut. If present in pancreas, gliadin could interact directly with the immune system and the beta cells to initiate diabetes development. We orally and intravenously administered 33-mer and 19-mer gliadin peptide to NOD, BALB/c, and C57BL/6 mice and found that the peptides readily crossed the intestinal barrier in all strains. Several degradation products were found in the pancreas by mass spectroscopy. Notably, the exocrine pancreas incorporated large amounts of radioactive label shortly after administration of the peptides. The study demonstrates that, even in normal animals, large gliadin fragments can reach the pancreas. If applicable to humans, the increased gut permeability in prediabetes and type 1 diabetes patients could expose beta cells directly to gliadin fragments. Here they could initiate inflammation and induce beta cell stress and thus contribute to the development of type 1 diabetes.
\end{abstract}

\section{Introduction}

A gluten-free (GF) diet reduces the incidence of diabetes in nonobese diabetic (NOD) mice and DP-BB rats $[1,2]$. In humans, early exposure to gluten-containing food has been associated with increased risk of islet autoimmunity [3], and a recent case study has described a prolonged remission period in a type 1 diabetes (T1D) patient adhering to the GF diet $[4,5]$. Finally, up to $10 \%$ of T1D patients have coeliac disorders, compared to $1 \%$ of the background population, indicating a common pathogenesis in coeliac disease and T1D [6].

A gluten-containing diet affects immune cells in the pancreatic lymph nodes and possibly contributes to local inflammation. In healthy mice, gluten intake promotes a proinflammatory profile of regulatory T-cells in both mesenteric and pancreatic lymph nodes [7]. In BALB/C and NOD mice, we recently described changes in NK- and dendritic cell populations in pancreatic lymph nodes, when comparing GFwith a gluten-containing diet $[8,9]$. However, whether the effects of gluten take place in the intestinal immune system or by direct priming in the local lymph nodes and pancreas is unknown.

Much evidences suggest that gliadin peptides cross the intestinal barrier. After gluten intake, large gliadin fragments are found in the small intestine due to partial resistance of gliadin to digestive enzymes [10, 11]. Intestinal permeability and serum zonulin levels are increased in T1D patients even 
before clinical onset of the disease $[12,13]$. This may likely enhance the entry of gliadin fragments into lamina propria and lymphoid tissue. Finally, enterovirus infection, which is associated with $\mathrm{T} 1 \mathrm{D}$, increases the intestinal permeability [14]. After crossing the intestinal epithelium, it is likely that gliadin peptides enter the bloodstream. This is seen for other dietary proteins such as ovalbumin when administered orally to mice [15], and, in one study, gliadin has been demonstrated in serum and breast milk by ELISA [16], although the finding was never confirmed.

The current study investigates the murine uptake and biodistribution of 33-mer and 19-mer gliadin peptides. We used the proline-rich 33-mer (p56-88) and 19-mer (p3149) alpha-gliadin peptides, which are resistant to digestive proteases $[10,11,17]$ and widely studied due to their implication in coeliac disease (CD) $[18,19]$. Their transepithelial passage in vitro is low in healthy individuals compared to CD patients, in whom the fragments are transported by protected transcellular transport [17, 20, 21]. We show that these large gliadin peptides are present in circulation after oral administration and that large gliadin fragments access pancreas even in nondiabetic BALB/c and C57BL/6 mice. This may contribute to local inflammation and beta cell stress, which could accelerate the development of type 1 diabetes.

\section{Methods}

2.1. Gliadin Peptides. The peptides H-LQLQPFPQPELPYPQPELPYPQPELPYPQPQPF-OHY (33-mer) and H-LGQQQPFPPQQPYPQPQPF-OHY (19-mer), 98\% pure (Schafer-

$\mathrm{N}$, Denmark), were ${ }^{3} \mathrm{H}$-labeled in the underlined positions using diiodotyrosine $\left(\mathrm{Y}\left(3,5-\mathrm{I}_{2}\right)\right)$ iodinated peptides by standard technique $[22,23]$. They were dissolved in DMSO, mixed with $10 \%$ palladium on carbon catalyst, and subjected to $10 \mathrm{Ci}$ tritium gas in a tritium manifold system (RC Tritec) for $2 \mathrm{~h}$ at room temperature, then purified by HPLC, and conserved by addition of $50 \mathrm{mM}$ ascorbic acid. $\mathrm{pH}$ was 7.5 for intravenous use (i.v.) and 6 for peroral (p.o.) use. Radiochemical stability was 10 days, during which the animal experiments were performed.

2.2. Mice. BALB/cA BomTac (males), C57BL/6JBomTac (males), and NOD/MrkTac mice were purchased from Taconic Europe A/S, Ejby, Denmark, kept in an SPF animal facility and fed standard Altromin 1324 diet. NOD mice were bred in the same facility. Animal experiments were approved by the Danish Animal Experiments Inspectorate and experiments performed according to international guidelines for the care and use of laboratory animals.

2.3. Liquid Chromatography-Mass Spectrometry (LC-MS). $\mathrm{BALB} / \mathrm{c}$ mice, $4-16$ weeks of age, were given $650-900 \mu \mathrm{g}$ of 33-mer, either i.v. or p.o., and heparin-plasma was prepared 15-60 min later at $0^{\circ} \mathrm{C}$. Protein inhibitors were added to the tissues that were homogenized, mixed with internal standard (GENESEQP:AZF58701), and precipitated with 50\% methanol, 1\% TFA, and centrifugation. The samples were analyzed using an Orbitrap XL (Thermo Scientific) equipped with a Nano LC (Easy nLC II, Thermo Scientific). The chromatographic system was a $10 \mathrm{~cm}$, ID $75 \mu \mathrm{m}, 3 \mu \mathrm{m} \mathrm{C18-}$ A2 column (Thermo Scientific) with a flow of $300 \mathrm{~nL} / \mathrm{min}$ with $0.1 \%$ formic acid as mobile phase A and $0.1 \%$ formic acid in acetonitrile as B. The MS scan was performed using a resolution of 30000 and a scan range of $300-2000 \mathrm{~m} / z$.

2.4. SDS-PAGE Analysis. Six mice received $230-1200 \mu \mathrm{Ci}$ of ${ }^{3} \mathrm{H}-33$-mer or ${ }^{3} \mathrm{H}-19-$ mer i.v. or p.o. or $200 \mu \mathrm{Ci}$ of ${ }^{3} \mathrm{H}$ tyrosine (Perkin Elmer). Heparin-plasma was prepared from tail blood at $0^{\circ} \mathrm{C}$ and analysed by SDS-PAGE without further processing, after depletion of albumin and IgG using a commercial kit (Protea Biosciences) or after digestion with trypsin (incubation with $125 \mathrm{mM}$ dithiothreitol, $0.05 \%$ SDS at $53^{\circ} \mathrm{C}$, pH 7.5 for $45 \mathrm{~min}$, followed by digestion with trypsin (Fluka) at $37^{\circ} \mathrm{C}$ ). The gel was fixed in $15 \%$ formalin $/ 25 \%$ ethanol and Coomassie-stained. For fluorography, the fixed gels were soaked in 7\% glycerol and Amplify Fluorographic Reagent (GE Healthcare), each for $30 \mathrm{~min}$, dried, and exposed on Amersham Hyperfilm MP at $-80^{\circ} \mathrm{C}$. Subsequently, the dried gels were rehydrated in $7 \%$ acetic acid for $2-4 \mathrm{~h}$ and Coomassie-stained.

For scintillation counting, gel slices were excised from the nonfixed gel, covered with $600 \mu \mathrm{L}$ of $30 \%$ hydrogen peroxide, and heated at $50^{\circ} \mathrm{C}$ overnight before measurement.

2.5. Matrix-Assisted Laser Desorption Ionization Time-ofFlight Mass Spectrometry (MALDI-TOF MS). Plasma was fractionated in Amicon Ultra $10 \mathrm{kDa}$ centrifugal filter units (Merck Millipore), Vivaspin 500, $5 \mathrm{kDa}$ filter units (Sartorius), PD10 columns, Amicon Ultra $0.5 \mathrm{~mL} 10 \mathrm{kDa}$ centrifugal filters, or SEP-PAK C18 Plus short cartridges (Waters), or they were ethanol-precipitated or acid-ethanol extracted. Slices from nonfixed gels were extracted overnight at $37^{\circ} \mathrm{C}$ in $100 \mu \mathrm{L}$ of $50 \mathrm{mM} \mathrm{NH} \mathrm{CO}_{3}$ with or without $12.5 \mathrm{ng} / \mu \mathrm{L}$ Endoproteinase Glu-C Sequencing Grade (Roche Diagnostics). The gel slices were further extracted on a shaker for $15 \mathrm{~min}$ in $20 \mu \mathrm{L}$ extraction buffer $(1: 2$ ( $\mathrm{vol} / \mathrm{vol})$ $50 \mathrm{mM} \mathrm{NH} \mathrm{NHCO}_{3}$ /acetonitrile). The extracts were combined.

Samples were dried in a vacuum concentrator (Eppendorf 5301) and reconstituted in $20 \mu \mathrm{L} 5 \%$ acetic acid before desalting using POROS C18 matrix and elution onto a stainless steel 96-well MALDI target plate with $1 \mu \mathrm{L} \alpha$ cyano-4-hydroxycinnamic acid (HCCA matrix) ready-made from Agilent $(6 \mathrm{mg} / \mathrm{mL}$ in $30 \%$ acetonitrile, $30 \%$ methanol, and $0.1 \%$ TFA) for dried droplet crystallization. Analysis was done on Bruker Ultraflex with Daltonics flexAnalysis software, externally calibrated using a standard peptide mixture (Bruker, range: 1,000-3,200 Da). Spectra were recorded in positive linear mode and summed from 100 laser shots.

The MS mass of 84 fragments $>800$ Da was calculated. They were randomly generated from the 33-mer sequence, allowing for deamidation of up to two glutamine residues (only one deamidation for $\mathrm{Mr}<1500 \mathrm{Da}$ ) and for sodium and potassium ion adduct formation. Measured masses were matched to the predicted masses, using a difference of $<0.5 \mathrm{Da}$ as threshold. Masses from negative control samples were matched using a threshold of 1.0 and removed. 
2.6. Biodistribution. For initial evaluation of accumulation and elimination in blood, NOD mice (6-8 weeks) received 230-900 $\mu \mathrm{Ci}{ }^{3} \mathrm{H}-33$-mer or ${ }^{3} \mathrm{H}-19-m e r$. For biodistribution experiments, BALB/c, C57BL/6, and NOD mice (8 or 12 weeks) received $50 \mu \mathrm{Ci}(1.5-3.6 \mathrm{nmol})$ of 33 -mer or 19 -mer, either p.o. or i.v., and NOD mice aged 20 weeks received $25 \mu \mathrm{Ci}(0.5 \mathrm{nmol}){ }^{3} \mathrm{H}$-tyrosine. Organs were incubated with SOLVABLE (Perkin-Elmer) at $55^{\circ} \mathrm{C}$ until dissolved and then with $30 \%$ hydrogen peroxide to decolorize the solution. Ultima Gold (Perkin Elmer) was added, and samples were counted $1 \mathrm{~h}$ later in a Packard 1600TR scintillation counter.

Specific activities ( $\mathrm{dpm} / \mathrm{mg}$ tissue) were calculated by dividing the counts by the respective weight of the sample that was measured. The tissue distribution was examined using the tissue/blood ratios. To compare responses in blood across different doses (230-900 $\mu \mathrm{Ci})$, data were normalized to a dosage of $100 \mu \mathrm{Ci}$.

For kinetics studies, using SDS-PAGE and fluorography, $230 \mu \mathrm{Ci}{ }^{3} \mathrm{H}$-33-mer or $770 \mu \mathrm{Ci}$ of ${ }^{3} \mathrm{H}-19$-mer was used for i.v. administration and $620-1200 \mu \mathrm{Ci}{ }^{3} \mathrm{H}-33$-mer was used for oral administration to NOD mice aged $6-8$ weeks. One NOD mouse aged 20 weeks received $200 \mu \mathrm{Ci}^{3} \mathrm{H}$-tyrosine.

Before oral gavage, mice were starved for $4 \mathrm{~h}$ and were not fed until 20 min after.

2.7. Autoradiography. Standard tissue sections were dipped in a 1:1 dilution in water of melted Kodak NTB Emulsion with 10\% Amplify Fluorographic Reagent (GE Healthcare), air-dried, stored in the dark at $4^{\circ} \mathrm{C}$ with desiccant for 1-3 weeks, developed in Kodak D19 developer, fixed in Ilford Rapid Fixer, HE stained, and examined in an Olympus Bx51 microscope (UPlanSApo 20x, 0.40) equipped with a Colorview 1 camera and Analysis getIT software (Olympus).

2.8. Statistical Analysis. One-way ANOVA with Tukey posttest was carried out using GraphPad Prism version 5.00 for Windows (GraphPad Software, San Diego, California, USA) to analyze the distribution of the label at each time point. The stomach and intestine were excluded from the analysis due to their large variation. The age of the animals ( 8 and 12 weeks) did not influence the uptake or distribution of radioactivity from the ${ }^{3} \mathrm{H}-33$-mer peptide. Thus, mice of different ages were pooled.

\section{Results}

To test the hypothesis that large gluten fragments might be absorbed from the intestine, two fragments that have been well investigated in coeliac disease, gliadin 33- and 19-mer, were tritium-labeled and given orally to NOD mice, and blood and tissues were sampled up to 72 hours after administration (Figure 1(a)). Interestingly, a high level of label from both fragments was seen in the pancreas shortly after administration $(0.01<p<0.05)$. To increase the time resolution for this phenomenon, we looked in detail at the early events in NOD mice (Figure 2(b)) and found that the label was present $1 / 2 \mathrm{~h}$ after administration and still remained 3 hours after oral administration. A tyrosine control was included to simulate enzymatic degradation of the peptides, since the label was introduced into the peptides through this amino acid. This label accumulated similarly to the 33- and 19-mer, suggesting that degradation of the peptides could account for the accumulation of label.

To investigate if the intestinal transfer of tracer was specific for NOD mice, we also investigated BALB/c and C57BL/ 6 mice. In these strains, similar findings were seen (Figure 2), suggesting that the enteric permeability for gluten peptides was not specific for NOD mice and that the pancreatic accumulation of the label occurs similarly in several strains.

For reference, we investigated the absorbance and distribution of gliadin fragments following intravenous injection and observed an even more pronounced accumulation of label (Supp. Figure 1A (see Supplementary Material available online at http://dx.doi.org/10.1155/2016/2424306)). Again, the results did not differ when investigating the matter in BALB/C mice (Supp. Figure 1B).

To investigate the spatial distribution of the radiolabel, we performed autoradiography. In pancreas (Figure 3(a)), the majority of the label was present in the zymogen granules of the exocrine pancreas and in the duct system and to a lesser extent in the islets. In the other tissues examined (lung (b), kidney (c), and ileum (d)), the label was less abundant and evenly distributed.

3.1. Analysis of Molecular Weight Species in the Blood. The results do not necessarily demonstrate the presence of the peptides in the various tissues, as the peptides might cleave during uptake [24]. This is in fact a distinct possibility, as investigated in Supp. Figure 2. In blood (Supp. Figure 2A), molecular weight species about twice the molecular weight of the peptide $(12 \mathrm{kDa})$ were seen within minutes of injection. After $1 \mathrm{~h}$, higher molecular weight species (HMW) emerged. Formation of the HMW species could be prevented by injecting unlabeled 33-mer, suggesting that the signals originated from 33-mer adsorbing to high molecular weight species or from tyrosine from the 33-mer that were incorporated into newly synthesized HMW molecules. The 19-mer (Supp. Figure $2 \mathrm{~B}$ ) showed similar behavior, except that the $12 \mathrm{kDa}$ signals were absent at $30 \mathrm{~min}$.

Blood analyses following oral administration showed similar results (Supp. Figure 2C), except again absence of the $12 \mathrm{kDa}$ signals. It is noticeable that the 33 -mer signal is still present in the blood, although in low amounts, $1 \mathrm{~h}$ after oral administration of the peptide. Interestingly, the $12 \mathrm{kDa}$ signal, but not the HMW signal, also formed in vitro (Supp. Figure 2D). This suggests that the $12 \mathrm{kDa}$ signal does not require de novo synthesis, whereas the HMW does.

To investigate the relation of the HMW signal with albumin and IgG, we selectively removed these molecules from blood samples from mice that had received 33-mer orally. This removed $35 \%$ of the label, regardless of the route of administration. If adding the ${ }^{3} \mathrm{H}-33$-mer to blood in vitro or if cold peptide was injected prior to injection of the labeled peptide, only $14-15 \%$ could be removed (Supp. Figure 2E). This suggests that the label was either associated with or synthesized into these molecules. Following trypsin digestion of serum, which degrades albumin, but not 33-mer (Supp. Figure $2 \mathrm{~F}$ ), no distinct band was released, suggesting that 

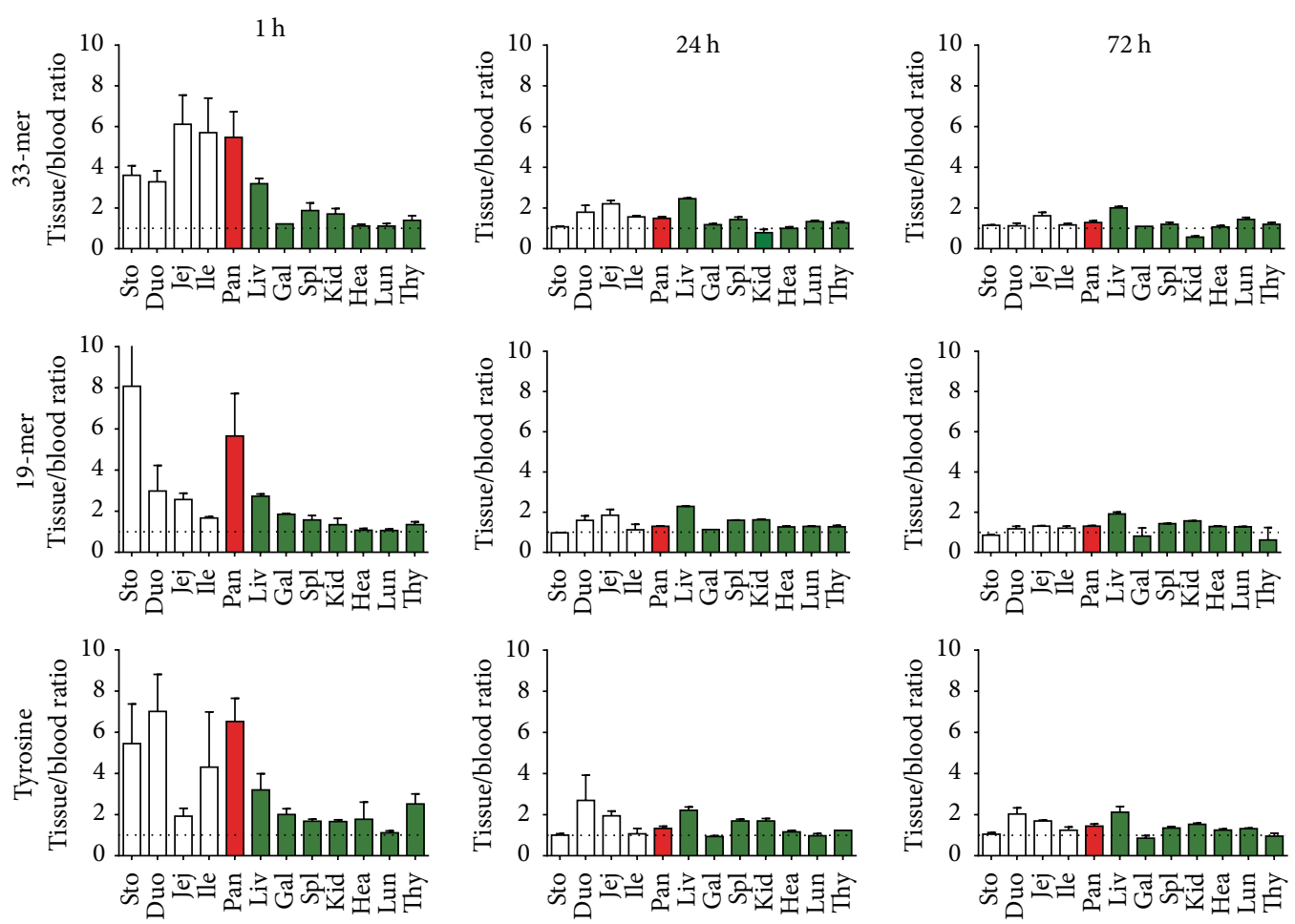

(a)
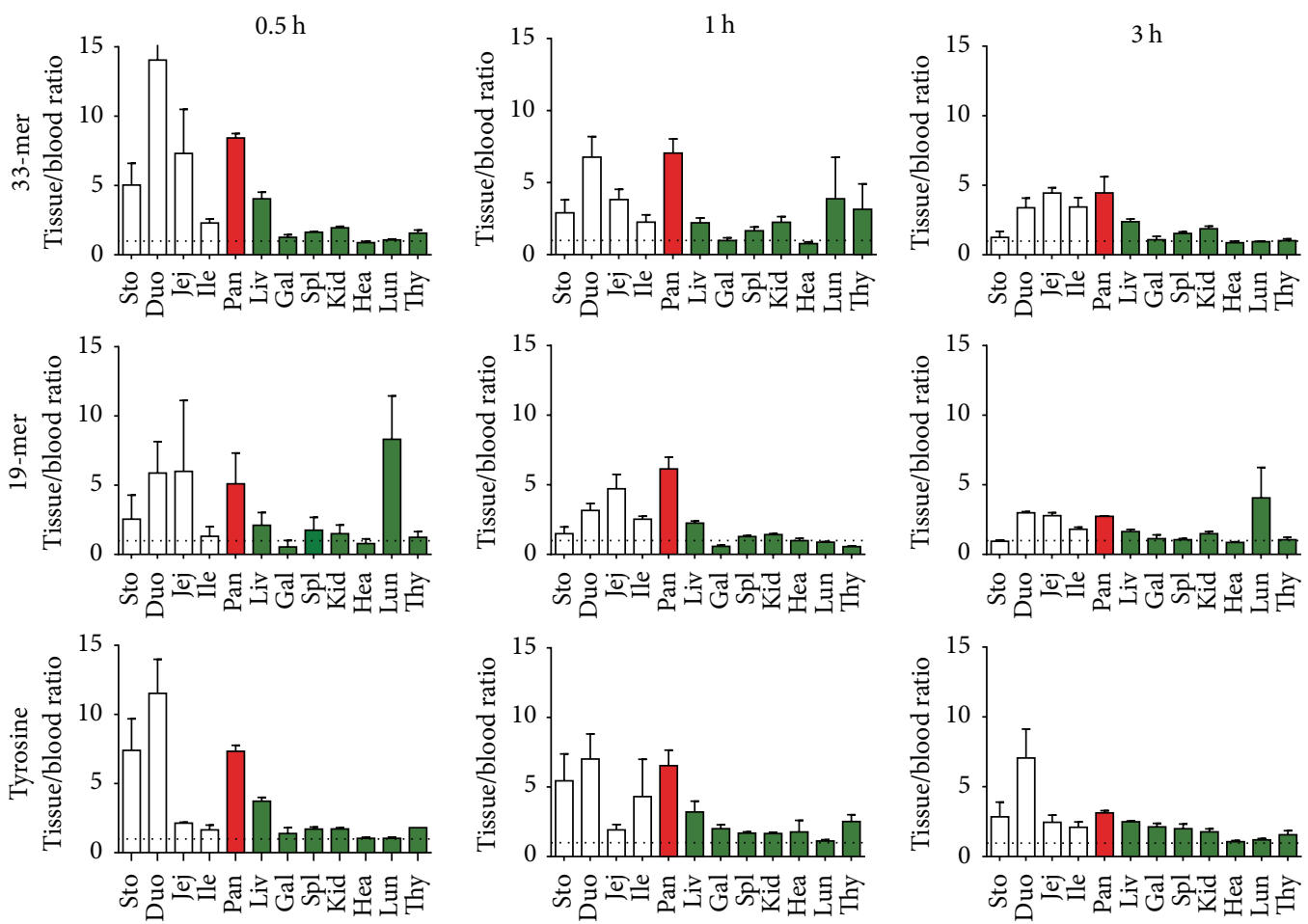

(b)

Figure 1: Quantification of ${ }^{3} \mathrm{H}-33$-mer, ${ }^{3} \mathrm{H}-19$-mer, and ${ }^{3} \mathrm{H}$-tyrosine following oral ingestion in NOD mice in intestine (white), pancreas (red), and other tissues (green). (a) Radioactivity relative to blood in selected tissues 1, 24, and $72 \mathrm{~h}$ after oral administration of ${ }^{3} \mathrm{H}$-33-mer to mice aged 8 and 12 weeks, of ${ }^{3} \mathrm{H}$-19-mer to mice aged 12 weeks, and of ${ }^{3} \mathrm{H}$ tyrosine to mice aged 20 weeks $(N=2-4$ mice). Error bars represent SEM. Sto (stomach), Duo (duodenum), Jej (jejunum), Ile (ileum), Pan (pancreas), Liv (liver), Gal (gallbladder), Spl (spleen), Kid (kidney), Hea (heart), Lun (lung), and Thy (thyroid gland). (b) Tissue distribution of ${ }^{3} \mathrm{H}-33$-mer, ${ }^{3} \mathrm{H}-19$-mer, and ${ }^{3} \mathrm{H}$-tyrosine tracer in NOD mice 0.5 , 1 , and 3 hours after oral administration. NOD mice (6-8 weeks) were given ${ }^{3} \mathrm{H}-33$-mer (upper), ${ }^{3} \mathrm{H}-19$-mer (middle), or ${ }^{3} \mathrm{H}$-labeled tyrosine (bottom). $N=4$ mice. Error bars represent SEM. The abbreviations are as above. 

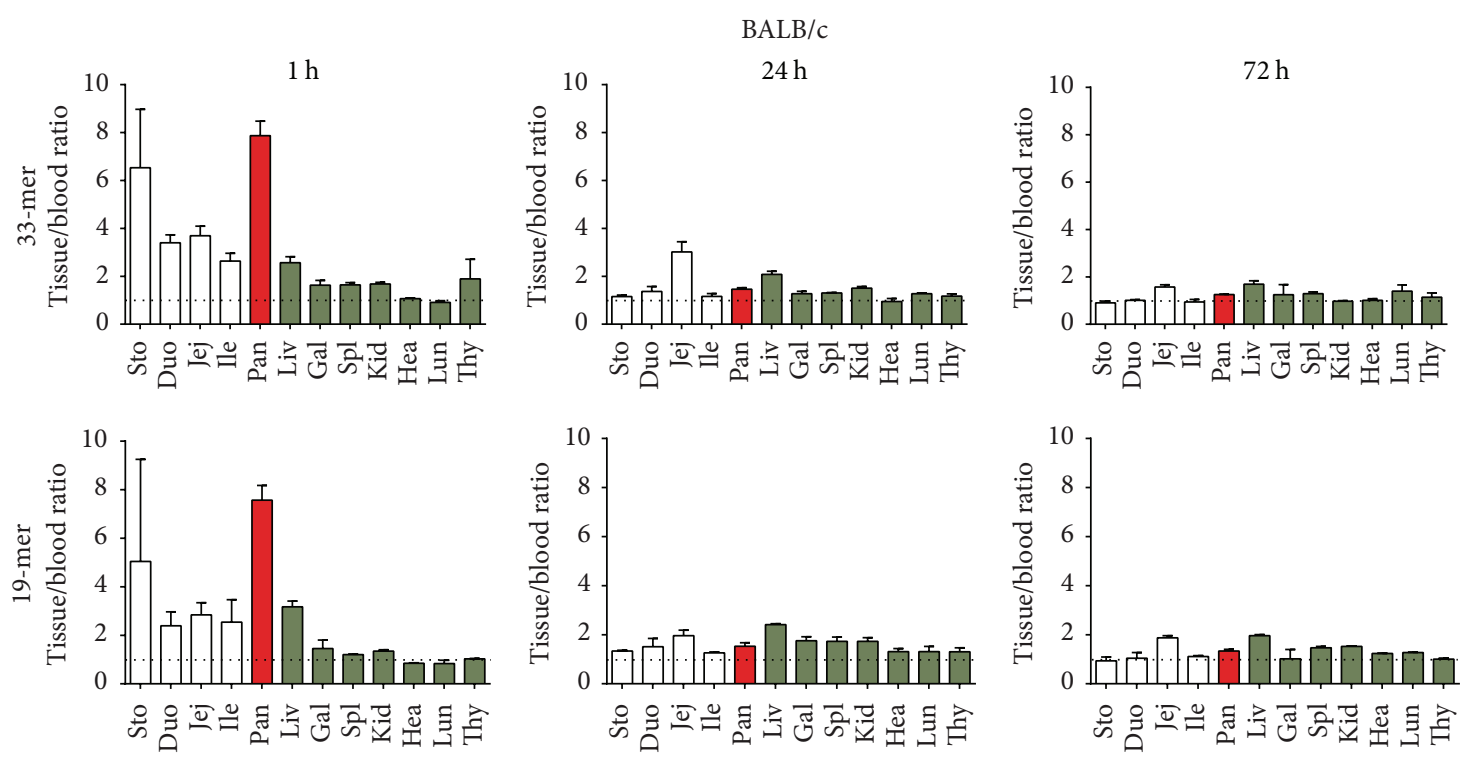

(a)
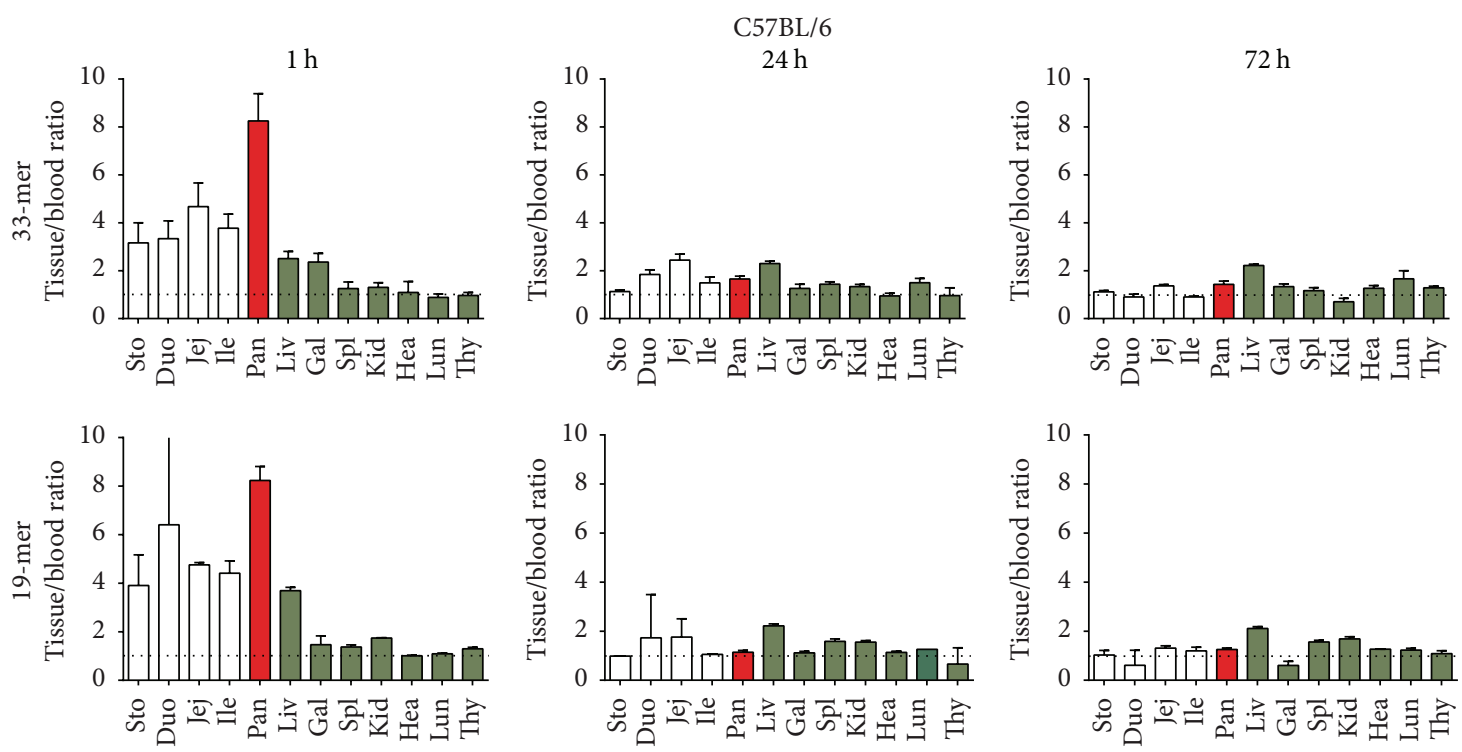

(b)

FIGURE 2: Tissue distribution of gliadin 33-mer and 19-mer following oral ingestion in BALB/c (a) and C57BL/6 mice (b), 8-12 weeks of age. Blood and organs were sampled after 1,24, and $72 \mathrm{~h}$. The specific radioactivity is shown relative to blood, and data are average values of $2-4$ mice and shown with SEM values. Abbreviations are as in Figure 1.

the HMW signals originate from de novo synthesis. Further, injection of ${ }^{3} \mathrm{H}$-tyrosine in mice results in appearance of the HMW band (data not shown). This is compatible with the delay in the appearance of the signal following oral ingestion (Supp. Figure 3A). In summary, our data are compatible with degradation of the 33-mer in vivo.

3.2. Mass Spectrometry Analysis of Blood and Tissue. We finally used mass spectrometry to identify the peptides. We first optimized the LC-MS detection of the 33-mer by different purification procedures, using samples containing 33mer, plasma, and plasma spiked with 33-mer (Figure 4). We then analyzed blood from BALB/c mice that had received 33mer by intravenous or peroral administration and detected intact peptide in samples 15, 30, and 60 minutes after injection and $60 \mathrm{~min}$ after oral administration (Figure 4).

A total of 21 MALDI-TOF MS signals from blood and tissues could be matched to 33-mer fragments (Table 1). In blood, the longest peptide detected was a 32-mer, which was originally described as stable [11]. Using pancreas samples, the longest peptide observed was 16 amino acids. In NOD mice, we detected fragments in mice at $6,8,10$, and 20 weeks of age. Further, we demonstrated that many of the fragments are also generated in vitro (Table 2) if 33-mer is incubated with 
TABLE 1: 33-mer fragments in mouse plasma and pancreas 45-60 min after oral administration, as determined by MALDI-TOF MS.

\begin{tabular}{|c|c|c|}
\hline & LQLQPFPQPELPYPQPELPYPQPELPYPQPQPF & Sample \\
\hline 1 & YPQPQPF & Plasma, NOD \\
\hline 2 & FPQPELPY & Plasma, C57BL/6 \\
\hline 3 & QPFPQPELP & Plasma, NOD \\
\hline 4 & ELPYPQPELP & Plasma, NOD pancreas, C57BL/6 \\
\hline $5-1$ & LQLQPFPQPE & Pancreas, C57BL/6 \\
\hline $5-2$ & QLQPFPQPEL & \\
\hline $6-1$ & QPFPQPELPY & Pancreas C57BL/6 \\
\hline $6-2$ & ELPYPQPQPF & Plasma, NOD \\
\hline 7 & QLQPFPQPELP & Plasma, NOD \\
\hline 8 & ELPYPQPELPYP & Plasma, NOD pancreas, NOD \\
\hline 9 & QLQPFPQPELPY & Plasma, NOD, C57BL/6 \\
\hline 10 & ELPYPQPELPYPQ & Plasma, NOD \\
\hline 11 & YPQPELPYPQPQPF & Plasma, NOD, C57BL/6 \\
\hline 12 & LPYPQPELPYPQPQPF & Pancreas, NOD, C57BL/6 \\
\hline 13 & LQLQPFPQPELPYPQPE & Plasma, NOD \\
\hline 14 & ELPYPQPELPYPQPELPYPQPQ & Plasma, NOD plasma, NOD \\
\hline $15-1$ & QPFPQPELPYPQPELPYPQPELPYPQPQ & Plasma, NOD, C57BL/6 \\
\hline $15-2$ & LQLQPFPQPELPYPQPELPYPQPELPYP & \\
\hline $16-1$ & QPFPQPELPYPQPELPYPQPELPYPQPQP & Plasma, NOD, C57BL/6 \\
\hline $16-2$ & LQPFPQPELPYPQPELPYPQPELPYPQPQ & \\
\hline 17 & LQLQPFPQPELPYPQPELPYPQPELPYPQPQP & Plasma, C57BL/6 \\
\hline
\end{tabular}

Mice (6-20 weeks) were given 500-900 $\mu \mathrm{g}$ of 33-mer p.o. and blood and pancreas were analyzed. Samples were filtrates from $10 \mathrm{kDa}$ centrifugal filters, supernatant from ethanol precipitation, an acidic ethanol extract from pancreas, peptide fractions from a PD10 desalting column, fractions from SEP-PAK C18 columns, and slices from SDS-PAGE gels (extracted without Glu-C digestion). The 33-mer fragment sequences were identified by matching the observed masses to the masses predicted for a list of arbitrary 33-mer fragments. Predictions were done using the theoretical masses and mass changes allowing 1-2 deamidations of glutamine and binding of sodium and potassium ions.

TABLE 2: Fragments formed in vitro during incubation of 33-mer in mouse plasma, as determined by MALDI-TOF MS.

\begin{tabular}{|c|c|c|}
\hline & LQLQPFPQPELPYPQPELPYPQPELPYPQPQPF & Sample \\
\hline 1 & YPQPQPF & Filtrate \\
\hline 2 & ELPYPQPEL & Filtrate \\
\hline 3 & QPFPQPELPY & Filtrate \\
\hline 4 & YPQPELPYPQPQPF & Filtrate \\
\hline 5 & ELPYPQPELPYPQPEL & Filtrate \\
\hline 6 & LQLQPFPQPELPYPQPE & $4-6 \mathrm{kDa}$ \\
\hline 7 & ELPYPQPELPYPQPELPY & Filtrate \\
\hline 8 & ELPYPQPELPYPQPELPYPQPQPF & $14-18 \mathrm{kDa}$ \\
\hline 9 & FPQPELPYPQPELPYPQPELPYPQPQPF & $10-12 \mathrm{kDa}$ \\
\hline 10 & PFPQPELPYPQPELPYPQPELPYPQPQPF & $10-12 \mathrm{kDa}$ \\
\hline 11 & LQLQPFPQPELPYPQPELPYPQPELPYPQP & $14-18 \mathrm{kDa}$ \\
\hline 12 & QPFPQPELPYPQPELPYPQPELPYPQPQPF & $14-18 \mathrm{kDa}$ \\
\hline 13 & QLQPFPQPELPYPQPELPYPQPELPYPQPQP & $14-17 \mathrm{kDa}$ \\
\hline 14 & LQLQPFPQPELPYPQPELPYPQPELPYPQPQ & $14-17 \mathrm{kDa}$ \\
\hline 15 & LQLQPFPQPELPYPQPELPYPQPELPYPQPQP & $4-6 \mathrm{kDa}$ \\
\hline 16 & LQLQPFPQPELPYPQPELPYPQPELPYPQPQPF & $4-6 \mathrm{kDa}, 6-9 \mathrm{kDa}, 14-17 \mathrm{kDa}$ \\
\hline
\end{tabular}

33-mer was incubated at $37^{\circ} \mathrm{C}$ in mouse plasma, and samples were filtered through $5 \mathrm{kDa}$ MWCO centrifugal filters or run on SDS-PAGE gels before MALDITOF MS analysis. Approximate ranges of the gel slices, according to the molecular weight marker, are shown, and assignment of observed masses to 33-mer fragments was done as described in Table 1 . The appearance of bands at $10-20 \mathrm{kDa}$ on SDS-PAGE gels during incubation was confirmed before analysis of gel slices (not shown). The identified fragments at $10-18 \mathrm{kDa}$ were not found in plasma where 33 -mer was not added or when sampled at $t=0$. 


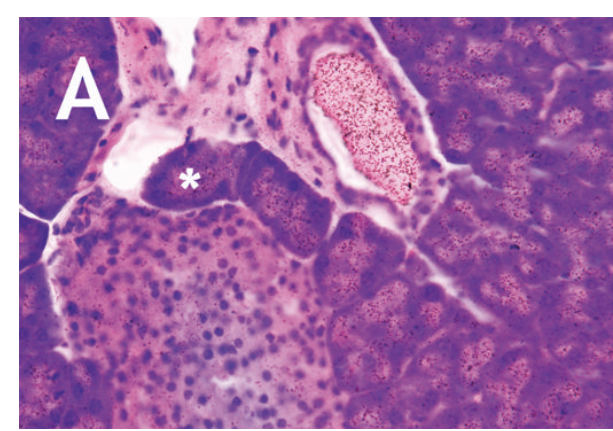

(a)

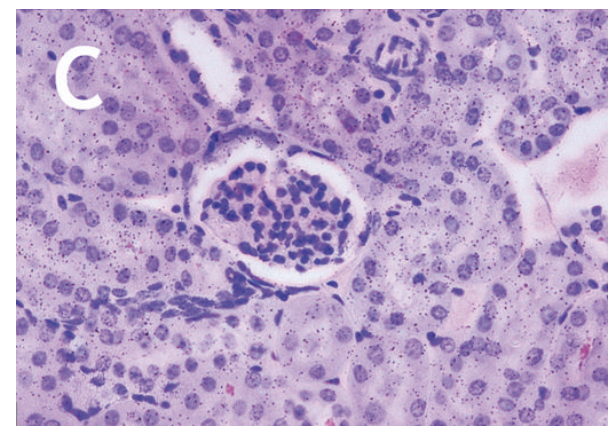

(c)

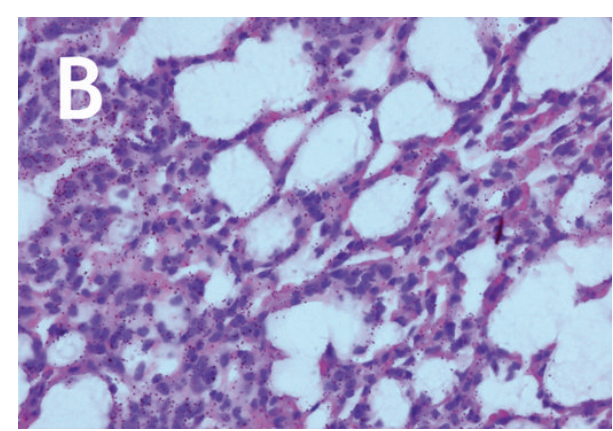

(b)

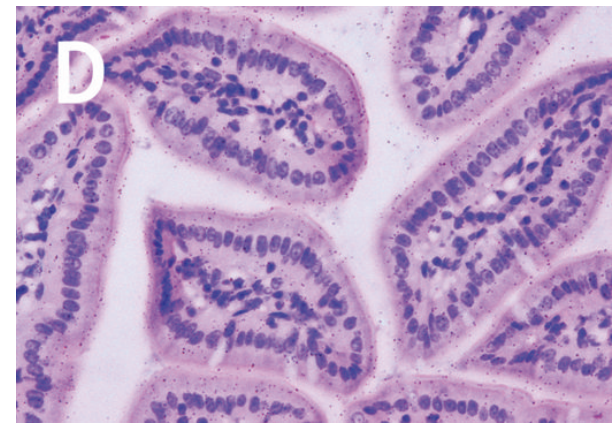

(d)

FiguRE 3: Autoradiography of mouse tissues following administration of ${ }^{3} \mathrm{H}-33$-mer. Mouse pancreas (a), lung (b), kidney (c), and ileum (d) were sampled $1 \mathrm{~h}$ after oral administration of ${ }^{3} \mathrm{H}-33$-mer. Asterisk denotes zymogen granules, which showed high accumulation of label. In all other tissues examined, homogenous labeling was observed. No difference was seen between i.v. and p.o. administration.

mouse plasma, suggesting that the fragments form as a result of proteolytic enzymes found in plasma.

\section{Discussion}

In this report, we demonstrated that 33-mer and 19-mer gliadin peptides are readily absorbed from the intestine of NOD mice and healthy BALB/c and C57 mice. We did not find differences related to the age or strain of the animals.

The absorption of gliadin peptides is complex. Gliadin stimulates zonulin expression, which in turn enhances the uptake of 33-mer by the paracellular route [25], and absorption is also affected by cytokines and gut bacteria [26-28]. It could be expected that the absorption is increased during development of diabetes, as increased capillary permeability is seen in the gut $[12,13,29,30]$ and in the islets [31,32] in type 1 diabetes patients, prediabetes patients, and relatives and in the $\mathrm{BB}$ rat model [33]. In NOD mice, the issue is less clear. Infection with a bacterial pathogen (Citrobacter rodentium) that can increase the intestinal permeability in NOD mice also increases disease incidence [34], but a change in permeability alone does not affect the disease mechanisms [35].

Nondegraded gliadin was previously identified in human breast milk [16] and in blood plasma in Wistar rats [26]. In addition, gliadin fragments have been demonstrated in animals under pathological conditions: in Rhesus macaques suffering from gluten-induced enteropathy or when sensitized to gluten [36]. Absorption of other macromolecules (ovalbumin and $\beta$-lactoglobulin) has been described, but in general the bioavailability is low and the half-life short of orally delivered peptide drugs and bioactive peptides $[37,38]$. Therefore, our observation of 33-mer crossing the gut barrier in healthy mice is interesting in the light of the few similar reports describing dietary protein fragments of significant length, crossing the intestinal epithelium [39].

It is difficult to quantify the daily intake of 33-mer as the gliadin content in crop is variable, but based on data from [40] and, assuming that a mouse ingests $5 \mathrm{~g}$ of food per day, we estimate that the intake is $50-100 \mu \mathrm{g}$. The native, amidated form of the 33-mer was not included in our studies, but since tissue transglutaminase is present in the intestine, it is likely that gliadin is at least partly deamidated before absorption. We therefore believe that the chosen dosages and peptides reflect the physiological exposure to gliadin.

We observed 10-20 kDa bands on SDS gels, which contained 33-mer and fragments hereof. The bands could be SDS-resistant, noncovalent di-, tri-, and multimers [41] in agreement with the ability of the (native, nondeamidated) 33-mer to dimerize and assemble into supramolecular structures, such as colloidal nanospheres [42]. Polymerized gliadin fragments could possibly accelerate the development of T1D, as multivalent surface presentation of epitopes [43] and particulate material [44] can more efficiently elicit immune responses. Self-assembly of the 33-mer might also protect it from enzymatic degradation or influence the uptake mechanism in the gut.

Other mechanism may, however, also explain the supernumerary gel bands. Deamidation of glutamines increases 

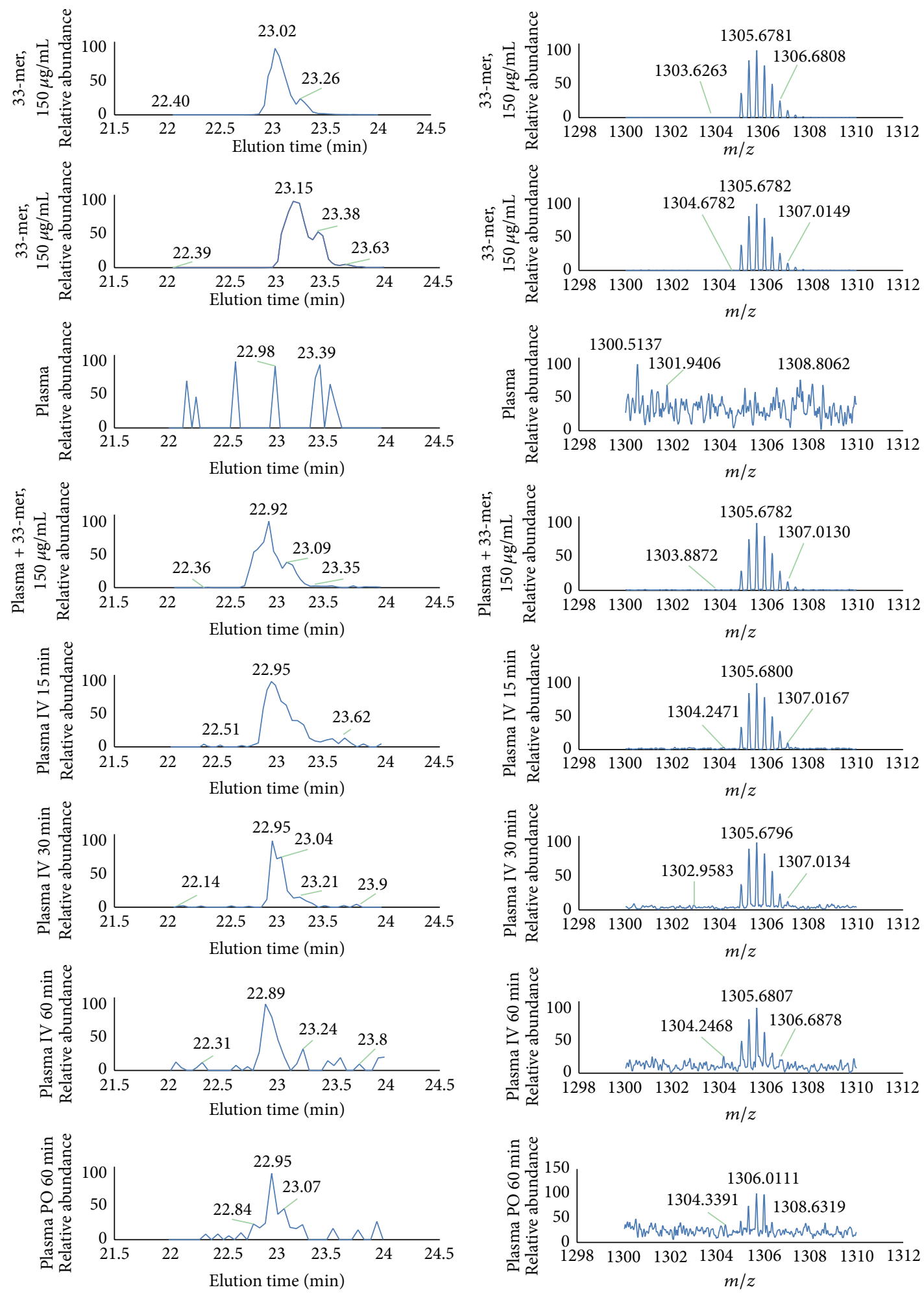

(a)

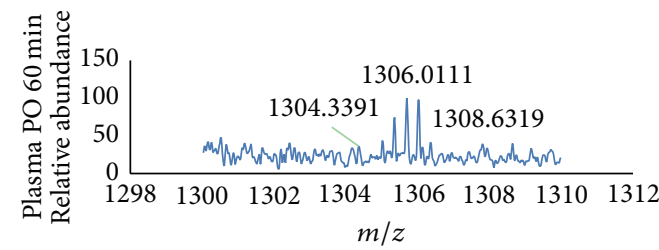

(b)

FIgURE 4: Analysis of plasma after administration of 33-mer to BALB/c mice by LC-MS. (a) Total ion current chromatograms with the 33-mer eluting at approximately $22.9 \mathrm{~min}$. (b) Averaged mass spectra corresponding to the elution profiles. Plasma was precipitated with methanolTFA before analysis. Rows 1-4 show control samples: 33-mer at $150 \mu \mathrm{g} / \mathrm{mL}$ (rows 1 and 2), plasma (row 3), and plasma added $150 \mu \mathrm{g} / \mathrm{mL}$ 33-mer (row 4). Rows 5-7 show plasma obtained 15, 30, and 60 min, respectively, after i.v. administration of $850 \mu \mathrm{g} 33$-mer, and row 8 shows plasma obtained $60 \mathrm{~min}$ after p.o. administration of $650 \mu \mathrm{g} 33$-mer. The levels after p.o. administration were close to the detection limit, and the peptide was not detected in all mice. 
the number of negatively charged residues, thus decreasing the migration rate [45]. Prolyl cis-trans isomerization of gliadin fragments [46] could result in more rigid conformations that move slower in the gel [47] and could form as the 33-mer [42] and other gliadin sequences [48] are able to form PPII helix structure, which might exist at the denaturing conditions. In blood, the two latter phenomena could be promoted by enzymes (e.g., transglutaminases and prolyl isomerases), but spontaneous reactions are also possible.

The demonstration of gliadin fragments in islets provides new insight into how gliadin might contribute to diabetes development. The observation that gliadin readily or as a result of increased zonulin secretion [49] penetrates the gut, even in healthy animals and irrespective of the genetic background, suggests that gluten contributes to the pathogenesis of the disease. Thus, beta cells are most likely also exposed to the gliadin fragments as their molecular weight $(4 \mathrm{kDa})$ is lower than capillaries retain [50]. This would cause stimulation of the insulin secretion, under both resting and glucosestimulated conditions [51], and lead to beta cell stress. Further, gliadin contributes to local inflammation as it induces a more proinflammatory cytokine profile among T-cells in the intestinal and extraintestinal lymphatic centers [7], reduces the number of regulatory T-cells in BALB/c mice [52], stimulates NKG2D expression [53] and NK cell activity [8] in $\mathrm{BALB} / \mathrm{C}$ and NOD mice, increases expression of dendritic cell activation markers in NOD mice [9], and, at least in vitro, activates macrophages [54]. These changes could all contribute to beta cell destruction.

How this suggested sequence of events translates into the human disease is not known, but several pathogenic aspects are similar in human and murine disease. For instance, gliadin also increases permeability in human intestinal mucosa [25], and recently a prolonged remission period among newly diagnosed TiD patients on a gluten-free, lowglycemic diet [55] was demonstrated. If the immunological consequences of gliadin exposure are similar in humans, the findings in the present study represent a missing link for understanding how gliadin contributes to the disease development.

\section{Competing Interests}

The authors declare that they have no conflict of interests.

\section{Acknowledgments}

This study was supported by Kirsten og Freddy Johansens Fond.

\section{References}

[1] D. P. Funda, A. Kaas, T. Bock, H. Tlaskalová-Hogenová, and K. Buschard, "Gluten-free diet prevents diabetes in NOD mice," Diabetes/Metabolism Research and Reviews, vol. 15, no. 5, pp. 323-327, 1999.

[2] R. B. Elliott and J. M. Martin, "Dietary protein: a trigger of insulin-dependent diabetes in the BB rat?" Diabetologia, vol. 26, no. 4, pp. 297-299, 1984.
[3] R. Chmiel, A. Beyerlein, A. Knopff, S. Hummel, A.-G. Ziegler, and C. Winkler, "Early infant feeding and risk of developing islet autoimmunity and type 1 diabetes," Acta Diabetologica, vol. 52, no. 3, pp. 621-624, 2014.

[4] J. M. Norris, K. Barriga, G. Klingensmith et al., "Timing of initial cereal exposure in infancy and risk of islet autoimmunity," The Journal of the American Medical Association, vol. 290, no. 13, pp. 1713-1720, 2003.

[5] S. M. Sildorf, S. Fredheim, J. Svensson, and K. Buschard, "Remission without insulin therapy on gluten-free diet in a 6year old boy with type 1 diabetes mellitus," BMJ Case Reports, vol. 2012, 2012.

[6] K. Buschard, "What causes type 1 diabetes? Lessons from animal models," APMIS. Supplementum, no. 132, pp. 1-19, 2011.

[7] J. C. Antvorskov, P. Fundova, K. Buschard, and D. P. Funda, "Dietary gluten alters the balance of pro-inflammatory and antiinflammatory cytokines in T cells of BALB/c mice," Immunology, vol. 138, no. 1, pp. 23-33, 2013.

[8] J. Larsen, M. Dall, J. C. Antvorskov et al., "Dietary gluten increases natural killer cell cytotoxicity and cytokine secretion," European Journal of Immunology, vol. 44, no. 10, pp. 3056-3067, 2014.

[9] J. Larsen, C. Weile, J. C. Antvorskov et al., "Effect of dietary gluten on dendritic cells and innate immune subsets in BALB/c and NOD mice," PLoS ONE, vol. 10, no. 3, Article ID e0118618, 2015.

[10] J. L. Piper, G. M. Gray, and C. Khosla, "Effect of prolyl endopeptidase on digestive-resistant gliadin peptides in vivo," Journal of Pharmacology and Experimental Therapeutics, vol. 311, no. 1, pp. 213-219, 2004.

[11] L. Shan, Ø. Molberg, I. Parrot et al., "Structural basis for gluten intolerance in celiac sprue," Science, vol. 297, no. 5590, pp. 22752279, 2002.

[12] E. Bosi, L. Molteni, M. G. Radaelli et al., "Increased intestinal permeability precedes clinical onset of type 1 diabetes," Diabetologia, vol. 49, no. 12, pp. 2824-2827, 2006.

[13] A. Sapone, L. de Magistris, M. Pietzak et al., "Zonulin upregulation is associated with increased gut permeability in subjects with type 1 diabetes and their relatives," Diabetes, vol. 55, no. 5, pp. 1443-1449, 2006.

[14] T. Jalonen, E. Isolauri, M. Heyman, A.-M. Crain-Denoyelle, P. Sillanaukee, and T. Koivula, "Increased $\beta$-lactoglobulin absorption during rotavirus enteritis in infants: relationship to sugar permeability," Pediatric Research, vol. 30, no. 3, pp. 290-293, 1991.

[15] T. Matsubara, N. Aoki, T. Honjoh et al., "Absorption, migration and kinetics in peripheral blood of orally administered ovalbumin in a mouse model," Bioscience, Biotechnology and Biochemistry, vol. 72, no. 10, pp. 2555-2565, 2008.

[16] F. G. Chirdo, M. Rumbo, M. C. Añón, and C. A. Fossati, "Presence of high levels of non-degraded gliadin in breast milk from healthy mothers," Scandinavian Journal of Gastroenterology, vol. 33, no. 11, pp. 1186-1192, 1998.

[17] M. Heyman, J. Abed, C. Lebreton, and N. Cerf-Bensussan, "Intestinal permeability in coeliac disease: insight into mechanisms and relevance to pathogenesis," Gut, vol. 61, no. 9, pp. 1355-1364, 2012.

[18] L. Maiuri, C. Ciacci, I. Ricciardelli et al., "Association between innate response to gliadin and activation of pathogenic T cells in coeliac disease," The Lancet, vol. 362, no. 9377, pp. 30-37, 2003. 
[19] M. T. Bethune and C. Khosla, "Parallels between pathogens and gluten peptides in celiac sprue," PLoS Pathogens, vol. 4, no. 2, article e34, 2008.

[20] T. Rauhavirta, S.-W. Qiao, Z. Jiang et al., "Epithelial transport and deamidation of gliadin peptides: a role for coeliac disease patient immunoglobulin A," Clinical and Experimental Immunology, vol. 164, no. 1, pp. 127-136, 2011.

[21] T. Matysiak-Budnik, I. C. Moura, M. Arcos-Fajardo et al., "Secretory IgA mediates retrotranscytosis of intact gliadin peptides via the transferrin receptor in celiac disease," Journal of Experimental Medicine, vol. 205, no. 1, pp. 143-154, 2008.

[22] M. H. F. Pedersen and M. Baun, "Tritium labelling of PACAP38 using a synthetic diiodinated precursor peptide," Journal of Labelled Compounds and Radiopharmaceuticals, vol. 55, no. 1, pp. 1-4, 2012.

[23] R. Finn, "Chemistry applied to iodine radionuclides," in Handbook of Radiopharmaceuticals: Radiochemistry and Applications, pp. 423-440, John Wiley \& Sons, West Sussex, UK, 2003.

[24] P. Vlieghe, V. Lisowski, J. Martinez, and M. Khrestchatisky, "Synthetic therapeutic peptides: science and market," Drug Discovery Today, vol. 15, no. 1-2, pp. 40-56, 2010.

[25] J. Hollon, E. L. Puppa, B. Greenwald, E. Goldberg, A. Guerrerio, and A. Fasano, "Effect of gliadin on permeability of intestinal biopsy explants from celiac disease patients and patients with non-celiac gluten sensitivity," Nutrients, vol. 7, no. 3, pp. 15651576, 2015.

[26] M. T. Bethune, M. Crespo-Bosque, E. Bergseng et al., "Noninflammatory gluten peptide analogs as biomarkers for celiac sprue," Chemistry and Biology, vol. 16, no. 8, pp. 868-881, 2009.

[27] S. Ménard, N. Cerf-Bensussan, and M. Heyman, "Multiple facets of intestinal permeability and epithelial handling of dietary antigens," Mucosal Immunology, vol. 3, no. 3, pp. 247$259,2010$.

[28] A. Fasano, "Zonulin, regulation of tight junctions, and autoimmune diseases," Annals of the New York Academy of Sciences, vol. 1258, no. 1, pp. 25-33, 2012.

[29] J. Visser, J. Rozing, A. Sapone, K. Lammers, and A. Fasano, "Tight junctions, intestinal permeability, and autoimmunity: celiac disease and type 1 diabetes paradigms," Annals of the New York Academy of Sciences, vol. 1165, pp. 195-205, 2009.

[30] S. De Kort, D. Keszthelyi, and A. A. Masclee, "Leaky gut and diabetes mellitus: what is the link?" Obesity Reviews, vol. 12, no. 6, pp. 449-458, 2011.

[31] J. L. Gaglia, M. Harisinghani, I. Aganj et al., "Noninvasive mapping of pancreatic inflammation in recent-onset type-1 diabetes patients," Proceedings of the National Academy of Sciences of the United States of America, vol. 112, no. 7, pp. 2139-2144, 2015.

[32] G. Papaccio, "Insulitis and islet microvasculature in type 1 diabetes," Histology and Histopathology, vol. 8, no. 4, pp. 751759, 1993.

[33] M. E. De Paepe, M. Corriveau, W. N. Tannous, T. A. Seemayer, and E. Colle, "Increased vascular permeability in pancreas of diabetic rats: detection with high resolution protein A-gold cytochemistry," Diabetologia, vol. 35, no. 12, pp. 1118-1124, 1992.

[34] A. S. Lee, D. L. Gibson, Y. Zhang, H. P. Sham, B. A. Vallance, and J. P. Dutz, "Gut barrier disruption by an enteric bacterial pathogen accelerates insulitis in NOD mice," Diabetologia, vol. 53, no. 4, pp. 741-748, 2010.

[35] I. Hadjiyanni, K. K. Li, and D. J. Drucker, "Glucagon-like peptide- 2 reduces intestinal permeability but does not modify the onset of type 1 diabetes in the nonobese diabetic mouse," Endocrinology, vol. 150, no. 2, pp. 592-599, 2009.
[36] M. T. Bethune, E. Ribka, C. Khosla, and K. Sestak, "Transepithelial transport and enzymatic detoxification of gluten in glutensensitive rhesus macaques," PLoS ONE, vol. 3, article e1857, 2008.

[37] M. Foltz, P. C. van der Pijl, and G. S. M. J. E. Duchateau, "Current in vitro testing of bioactive peptides is not valuable," Journal of Nutrition, vol. 140, no. 1, pp. 117-118, 2010.

[38] C. F. Deacon, M. A. Nauck, M. Toft-Nielsen, L. Pridal, B. Willms, and J. J. Holst, "Both subcutaneously and intravenously administered glucagon-like peptide I are rapidly degraded from the NH2-terminus in type II diabetic patients and in healthy subjects," Diabetes, vol. 44, no. 9, pp. 1126-1131, 1995.

[39] D. Regazzo, D. Mollé, G. Gabai et al., "The (193-209) 17residues peptide of bovine $\beta$-casein is transported through Caco-2 monolayer," Molecular Nutrition \& Food Research, vol. 54, no. 10, pp. 1428-1435, 2010.

[40] C. V. Ozuna, J. C. M. Iehisa, M. J. Giménez, J. B. Alvarez, C. Sousa, and F. Barro, "Diversification of the celiac disease $\alpha$ gliadin complex in wheat: a 33-mer peptide with six overlapping epitopes, evolved following polyploidization," Plant Journal, vol. 82, no. 5, pp. 794-805, 2015.

[41] I. Pallarés, C. Berenguer, F. X. Avilés, J. Vendrell, and S. Ventura, "Self-assembly of human latexin into amyloid-like oligomers," BMC Structural Biology, vol. 7, article 75, 2007.

[42] M. G. Herrera, F. Zamarreño, M. Costabel et al., "Circular dichroism and electron microscopy studies in vitro of 33-mer gliadin peptide revealed secondary structure transition and supramolecular organization," Biopolymers, vol. 101, no. 1, pp. 96-106, 2014.

[43] J. S. Rudra, Y. F. Tian, J. P. Jung, and J. H. Collier, "A self-assembling peptide acting as an immune adjuvant," Proceedings of the National Academy of Sciences of the United States of America, vol. 107, no. 2, pp. 622-627, 2010.

[44] F. A. Sharp, D. Ruane, B. Claass et al., "Uptake of particulate vaccine adjuvants by dendritic cells activates the NALP3 inflammasome," Proceedings of the National Academy of Sciences of the United States of America, vol. 106, no. 3, pp. 870-875, 2009.

[45] Y. Guan, Q. Zhu, D. Huang, S. Zhao, L. Jan Lo, and J. Peng, "An equation to estimate the difference between theoretically predicted and SDS PAGE-displayed molecular weights for an acidic peptide," Scientific Reports, vol. 5, Article ID 13370, 2015.

[46] G. Iacomino, O. Fierro, S. D’Auria et al., "Structural analysis and Caco-2 cell permeability of the celiac-toxic A-gliadin peptide 31-55," Journal of Agricultural and Food Chemistry, vol. 61, no. 5, pp. 1088-1096, 2013.

[47] T. N. Kirkland, F. Finley, K. I. Orsborn, and J. N. Galgiani, "Evaluation of the proline-rich antigen of Coccidioides immitis as a vaccine candidate in mice," Infection and Immunity, vol. 66, no. 8, pp. 3519-3522, 1998.

[48] I. Parrot, P. C. Huang, and C. Khosla, "Circular dichroism and nuclear magnetic resonance spectroscopic analysis of immunogenic gluten peptides and their analogs," The Journal of Biological Chemistry, vol. 277, no. 47, pp. 45572-45578, 2002.

[49] A. Fasano, "Zonulin and its regulation of intestinal barrier function: the biological door to inflammation, autoimmunity, and cancer," Physiological Reviews, vol. 91, no. 1, pp. 151-175, 2011.

[50] K. Wasserman, L. Loeb, and H. S. Mayerson, "Capillary permeability to macromolecules," Circulation Research, vol. 3, no. 6, pp. 594-603, 1955.

[51] M. Dall, K. Calloe, M. Haupt-Jorgensen et al., "Gliadin fragments and a specific gliadin 33-mer peptide close KATP 
channels and induce insulin secretion in INS-1E cells and rat islets of langerhans," PLoS ONE, vol. 8, no. 6, Article ID e66474, 2013.

[52] J. C. Antvorskov, P. Fundova, K. Buschard, and D. P. Funda, "Impact of dietary gluten on regulatory T cells and Th17 cells in BALB/c mice," PLoS ONE, vol. 7, no. 3, Article ID e33315, 2012.

[53] E. H. Adlercreutz, C. Weile, J. Larsen et al., "A gluten-free diet lowers NKG2D and ligand expression in BALB/c and non-obese diabetic (NOD) mice," Clinical and Experimental Immunology, vol. 177, no. 2, pp. 391-403, 2014.

[54] K. E. Thomas, A. Sapone, A. Fasano, and S. N. Vogel, "Gliadin stimulation of murine macrophage inflammatory gene expression and intestinal permeability are MyD88-dependent: role of the innate immune response in celiac disease," The Journal of Immunology, vol. 176, no. 4, pp. 2512-2521, 2006.

[55] J. Svensson, S. M. Sildorf, C. B. Pipper et al., "Potential beneficial effects of a gluten-free diet in newly diagnosed children with type 1 diabetes: a pilot study," SpringerPlus, vol. 5, article 994, 2016. 


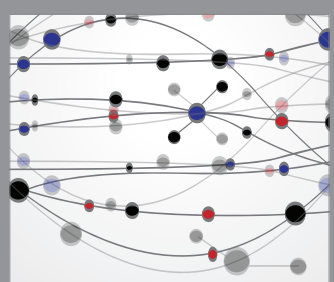

The Scientific World Journal
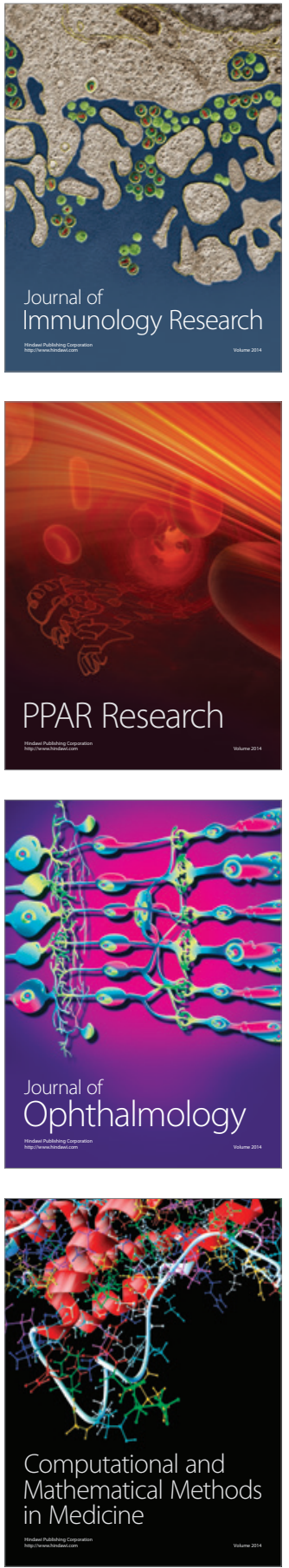

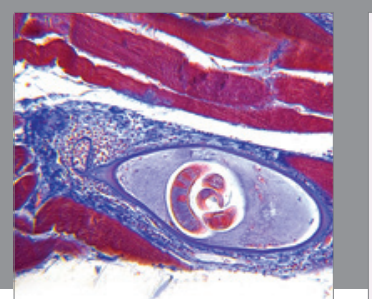

Gastroenterology Research and Practice

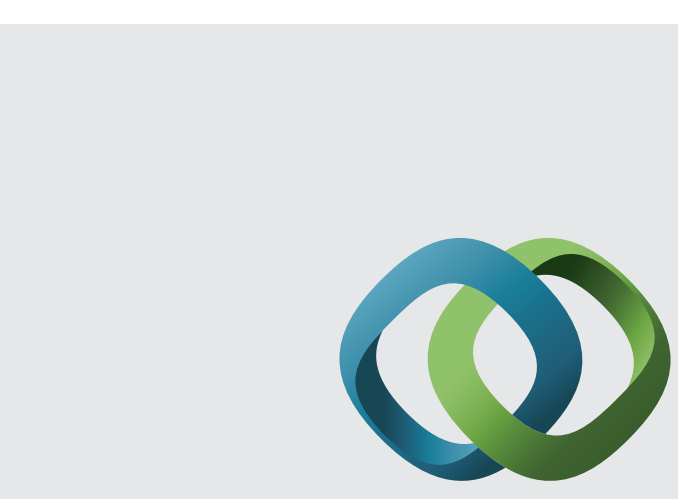

\section{Hindawi}

Submit your manuscripts at

http://www.hindawi.com
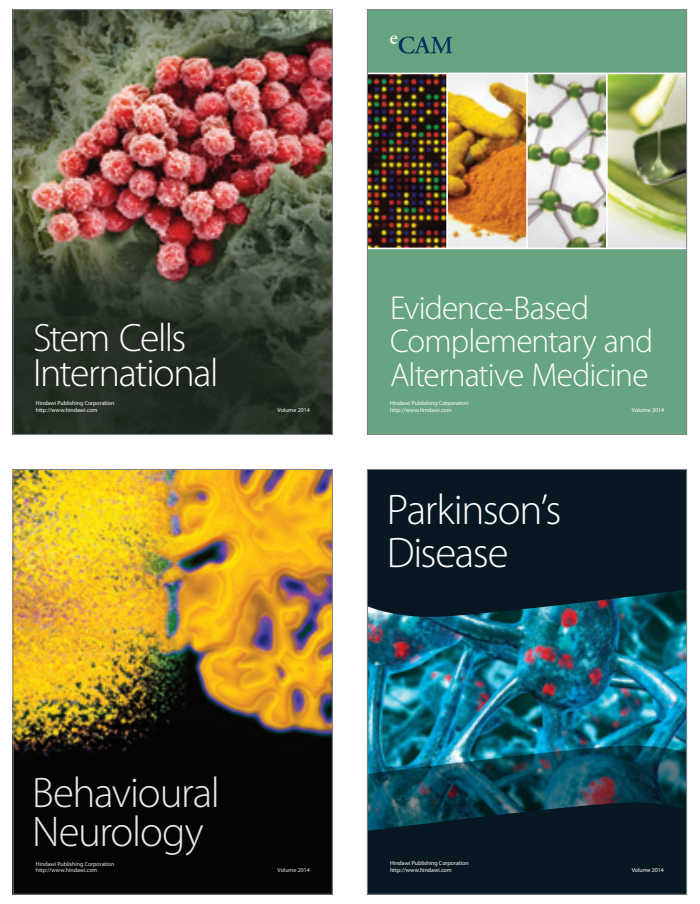
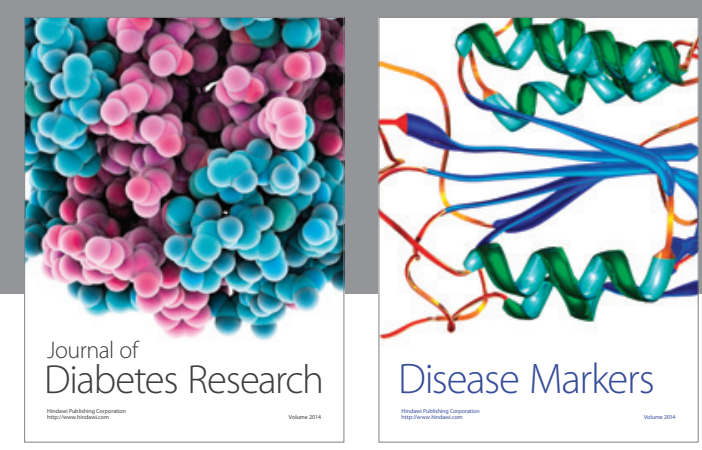

Disease Markers
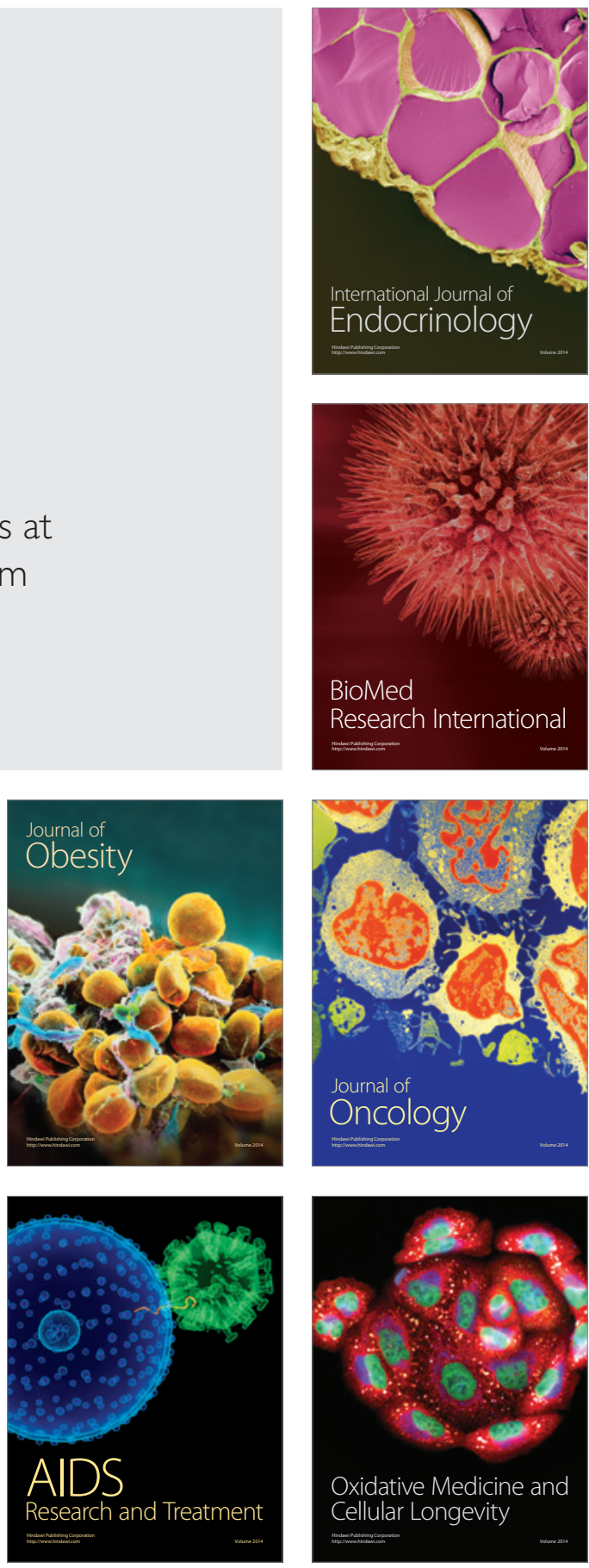